\title{
THERMODYNAMIC ANALYSIS AND SIMULATION OF STEAM TURBINE POWER PLANT HYBRID WITH PARABOLIC TROUGH COLLECTORS; A STUDY IN IRAQ
}

\author{
Ekin Özgirgin Yapıcı*, \\ Department of Mechanical Engineering, Çankaya University, Turkey, ekinozgirgin@cankaya.edu.tr \\ (iD) https://orcid.org/ 0000-0002-7550-5949) \\ Anwer Hamed Salih Al-Attwani \\ Department of Mechanical Engineering, Çankaya University, Turkey, anweralqurashi@yahoo.com \\ (iD) https://orcid.org/ 0000-0003-1733-9097)
}

Received: 08.03.2019, Accepted: 16.07.2019

*Corresponding author

\begin{abstract}
Fossil fuel thermal power plants are major investments for electricity production despite of their environmental drawbacks. Using solar energy in a hybrid manner with these power plants is a sensible and an economical choice for advanced power generation. In this study, thermodynamic analysis and simulation of a steam turbine power plant hybrid with parabolic trough solar collector field is done. Design process includes selection of heat transfer fluid (HTF), determination of the required solar power, orientation and sizing of the solar field, preliminary design of the solar heat exchanger (HEX) and thermodynamic analysis of the hybrid plant. After verification of computational model, simulations of steam power plant and hybrid power plant are done and results for increasing output electricity and saving fuel oil are studied considering the efficiency improvement and the environmental effects. Important solar field parameters like HTF, glass and absorber temperatures, heat loss coefficients and output power of the collector field are simulated and discussed. Finally, a simple economic analysis is done using levelized cost of energy method (LCOE) which showed that hybridization is economically sound. The study also suggests that, hybridization is a sensible choice for increasing efficiency and output power, decreasing use of fossil fuels, thus environment problems. The orientation of the hybrid connection plays an important role on these parameters.
\end{abstract}

Keywords: Solar Energy, Hybrid Thermal Power Plant, Parabolic Trough Collector, MATLAB, Economic Analysis

\section{IRAK'TA PARABOLİK OLUK TİII GÜNEŞ KOLLEKTÖRLÜ HİBRİT BUHAR SANTRALİNIN TERMODINAMIKK ANALIZII VE SIMUÜLASYONU}

\section{Özet}

Pek çok ülkede elektrik üretimi çevre için zararlı olmalarına rağmen, büyük oranda fosil yakıtla çalışan termik santrallarla yapılmaktadır. Güneş enerjisinin bu halihazırdaki termik santrallarla entege edilmesi sureti ile hibrit şeklilde enerji üretimi birçok açıdan oldukça akılcı ve ekonomiktir. Bu çalışmada parabolik oluk tipi güneş kollektörlü hibrit buhar santralinin termodinamik analizi yapılmıştır. Tasarım süreci, solar kollektörlerde kullanılacak sıvının seçimini, kollektör sahasının ölçüleri ve kullanılacak kollektör sayısının tayinini, kollektör ve buhar santralını bağlayan ıSı eşanjörünün ön tasarımını ve son olarak da hibrit sistemin termal analizini içermektedir. Nümerik modelin doğrulanmasının ardından buhar santralı ve hibrit santralın simülasyonları yapılmış, güç artışı, verim iyileşmesi, yakıt tasarrufu ve çevresel etkiler incelenmiştir. Ayrıca güneş kollektörü sahasında üretilebilecek ekstra enerji miktarları hesaplanmış ve faydalı enerji, ısı kaybı faktörü, solar akışkan sıcaklıkları, cam ve soğurucu boru sıcaklıkları hesaplanmış ve birbirleri ile kıyaslanmıştır. Son olarak basit ekonomik analiz yapılmış, seviyelendirilmiş enerji maliyeti (LCOE) hesaplanmış ve hibrit santralın ekonomik açıdan da avantajlı olduğuna dikkat çekilmiştir. Çalışma, hibrit sistemin daha güvenilir, daha yüksek verimli olduğuna dikkat çekmektedir. Verim artışı, güç artışı, yakıt tasarrufu ve azalan su kullanımı miktarları hesaplanmış ve farklı durumlar için birbiri ile kıyaslanmıştır. Güneş sahasının santrala entegrasyonun da bu parametreler üstünde oldukça önemli bir rol oynadığı ispatlanmıştır.

Anahtar Kelimeler: Güneş Enerjisi, Hibrit, Termal Güç Santralı, Parabolik Oluk Tipi Güneş Kollektörü, MATLAB Simülasyonu, Ekonomik Analiz

Cite

Özgirgin Yapıcı E., (2019). “Thermodynamic Analysis and Simulation of Steam Turbine Power Plant Hybrid with Parabolic Trough Collectors;a Study in Iraq", Mugla Journal of Science and Technology, 5(2), 1-12. 


\section{Introduction}

With increasing global energy demand, thus electricity demand declared by The International Energy Outlook [1], environmental pollution is increasing day by day since a big part of electricity production depends on fossil fuels which contaminate the environment. Not only that, but also since fossil fuel resources are getting degraded gradually which in turn leads to more expensive prices, utilization of environmentally friendly, low emission, low price natural renewable energy resources are increasing. Especially since it is the most widely used renewable energy source, utilization of solar energy is spreading fast all over the world.

Rankine (steam turbine) cycle power plant is one of the most common technologies for producing electricity. Especially in Iraq, fuel oil fired Rankine power plants are popular because of low oil prices. But nevertheless, environmental pollution is becoming a bigger problem so it becomes compulsory to take some measures.

Hybridization of present steam cycle power plants with renewable energy sources is one of the preventions for a more effective, economical and more environmentally friendly production of electricity [2]. Yawen Zhao et. al. [3] pointed out that, in a high performance Rankine cycle, since the temperature of feed water flowing back to the boiler is about $300-350{ }^{\circ} \mathrm{C}$ which matches with the temperature of the solar heat that is collected from solar field. Therefore, solar heat can be best utilized to replace steam extractions and heat the feed water, which can increase the work output of a steam turbine. Also by this orientation of solar field, the solar area per kWe and cost for a storage system can be reduced through hybridization [4]. In the scope of this study, steam turbine power plant hybridization is proposed to be done with parabolic trough solar collector field just before the boiler.

Parabolic trough solar collectors (PTCs) are made from parabolic trough-shaped mirrors which reflect and concentrate direct solar radiation onto a receiver tube. [5]. Concentrating solar radiation reduces the absorber surface area with respect to the aperture area of collector and that helps to reduce the overall thermal losses. The energy absorbed from radiation is used to heat the HTF which flows through the receiver tube, covered by glass envelope. There usually is a vacuum space between the absorber tube and the glass cover to reduce the thermal loses. Also, the glass cover of the receiver is coated by anti-reflective material to decrease reflective losses. The absorber tubes are coated by high absorbance material with low emittance to enhance energy absorbed and decrease losses by emittance. PTCs have a high performance and good efficiency, and they can achieve temperatures up to $400{ }^{\circ} \mathrm{C}$ [6]. PTC's can be utilized connected to power plants, which make the efficiency of electric generation higher and utilization of fossil fuels lower.
PTCs have sun tracking systems since the collector should follow the sun rays in order to focus the light on the absorber tube. There are more than one kind of sun tracking systems such as single axis North to South, single axis East to West, two axis, rotatable axis etc. The selection of the tracking method depends on the location of the plant, operation times and the available investment opportunities including the solar area sizing [7].

Solar field design is one of the most important part for utilization of enough amount of solar energy during different times of the year [8]. A typical PTCs field is composed of a number of parallel rows each row composed of several collectors connected in series regarding the total temperature difference and the flow rate of the working fluid. To determine the solar field size and configuration, some parameters such as; the collector orientation, the date and time of design point, the location of the plant site and the kind of working fluid are to be determined for thermal performance [8].

To connect Rankine Cycle with the solar field, a heat exchanger is required to transfer heat from heat transfer fluid to the water coming from the feedwater pumps of the Rankine Cycle. HEX design depends on a lot of parameters and is a delicate subject. The working pressure, kind of working fluid, capacity and total amount of heat transfer are to be considered to find all design parameters such as thickness of the tubes, layout of the tubes, number of passes etc. [9].

For numerical simulation of such an hybrid power plant system, some programs like TRNSYS, MATLAB Simulink can be used [10]. Bakos and Tsechelidou, [2] simulated integrating PTCs with $300 \mathrm{MW}$ Ptolemais thermal power plant in Greece by using TRNSYS model. They proved that the efficiency is increased and the emissions of $\mathrm{CO}_{2}$ with flue gas and lignite consumption are reduced by the proposed plant. A steady state analysis of such an hybrid system will be good enough to see the changes of power output, some performance parameters such as efficiency, unit cost and pollution sources. This method can be used for assessment of hybridization with solar technologies and comparison of different techniques [11].

In the light of above, in this study, utilization of solar energy to be used in a steam turbine power plant in a hybrid manner is investigated. Analytical calculations and MATLAB simulations for thermal analysis of the heavy fuel oil steam power plant and the hybrid power plant with parabolic trough solar collector system are conducted. Comparison with the on-site data is done for the steam power plant case for verification of the model. After verification, comparison of the hybrid plant with the Rankine cycle and hybrid plant with its different modes of operation are done. Accurate results are found compared with other studies focusing on which preheaters are quitted from operation depending on the amount of the solar energy collected from the solar field for each season. 
Amount of water used in the power plant is also considered in this study, since it is an important parameter to decrease the water requirement in the Rankine cycle for the sake of environment.

Considering the study, it can be said that the environmental profile of a hybrid power plant can be identified and quantified for large scale industrial applications and the impact of hybridization considering some of the design parameters on economical aspects and performance can be determined.

\section{Methodology}

First of all, Rankine Cycle analytical calculations are done and these results are compared with the real data of one unit of Wassit thermal power plant, in Wassit, Iraq. After the verification of results, solar parameters calculation throughout the year, parabolic trough collector thermal and optical analysis and solar field design including selection and orientation of the solar collectors are conducted. Next, hybrid cycle analytical calculations are done. When all the results seem consistent, MATLAB Simulink construction for the Rankine Cycle and the hybrid cycle are done. After the preliminary design of the solar heat exchanger, simulation of different schemes and different modes of operation for the power plant are done. The final part is the comparison of the results and discussion.

During the design procedure, the heat transfer fluid is chosen as Therminol oil VP-1 for obtaining high temperatures (up to $395^{\circ} \mathrm{C}$ ), since it has boiling temperature around $257^{\circ} \mathrm{C}$ at 1013 mbar [8]. LS3 type PTCs are suggested to construct the solar field which is proposed to hybrid with one unit of Wassit thermal power plant.

In the scope of this study, main focus will be given to the solar energy calculations, thermal analysis of the parabolic though collectors, results of the different modes of the hybrid power plant and the comparison of the cases emphasizing the importance of such a hybridization on the thermal, economical and environmental improvements.

\subsection{Analytical Calculations of Thermal Power Plant}

Studied thermal power plant contains three stages of turbines (HP, IP and LP) in addition to seven CFHs, OFH, a boiler, a generator, a condenser, a CWP and other auxiliary equipment. First law of thermodynamics and re-generative Rankine-cycle calculations are done to find necessary properties, thermal efficiency and fuel consumption depending on real data for one unit of this power plant [12]. For the start, energy balance equation and thermal efficiency calculation can be seen in equations 1 and 2 respectively [13].

$$
\dot{\mathrm{Q}}-\dot{\mathrm{W}}_{\mathrm{cv}}+\dot{\mathrm{m}}_{\mathrm{i}}\left(\mathrm{h}_{\mathrm{i}}+\frac{\mathrm{V}_{\mathrm{i}}^{2}}{2}+\mathrm{gz}\right)-\dot{\mathrm{m}}_{\mathrm{e}}\left(\mathrm{h}_{\mathrm{e}}+\frac{\mathrm{V}_{\mathrm{e}}^{2}}{2}+\mathrm{gz}\right)=0
$$

$$
\eta_{\mathrm{th}}=\frac{\text { net work }}{\frac{\text { heat added }}{\eta_{b}}}
$$

For the thermal analysis, following assumptions are done:

- Each component in this cycle is considered as a control volume.

- The operation of turbines and pumps are considered as adiabatic processes.

- The liquid exits from the condenser is considered saturated.

- Kinetic and potential energy differences are neglected among each control volume.

- The differential pressures of the fluid in both boiler and preheaters are neglected.

- The expansion in traps is considered such as a constant enthalpy process $(\mathrm{Hi}=\mathrm{Ho})$.

- $\quad$ Condensate water exiting from CFHs and OFH is considered as saturated liquid at each specified pressure.

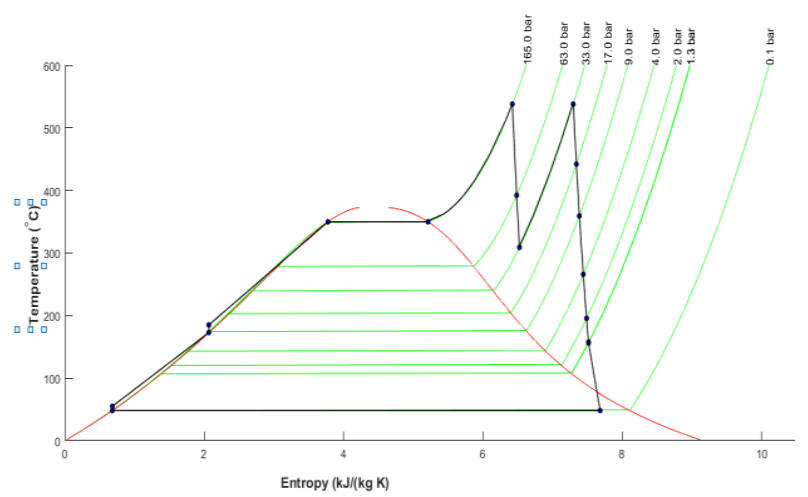

Figure 1. T-S diagram for Thermal Power Plant [14]

Thermodynamic analysis for Rankine cycle power plant can be found in ref [14] by Al-Attwani, which are done in the scope of this work. Figure 1 shows the T-S diagram for Wassit thermal power plant. The properties of working fluid are computed according to regenerative Rankine cycle using XSteam with MATLAB simulation which can be found in ref [14].

\subsection{Analytical Calculations of Hybrid Thermal Power Plant at Solar Time}

In this part, hourly solar energy calculations, thermal analysis of solar collectors, sizing of the solar field is done analytically. Orientation of the solar field is considered as to be just before the inlet of the water fed to the boiler [2]. Preliminary design of the solar heat exchanger (HEX) is also conducted and this analysis can be found in ref. [14] which is done by the scope of this work.

Two schemes are proposed considering the minimum and maximum values of solar power coming from the solar field depending on the month of the year. 


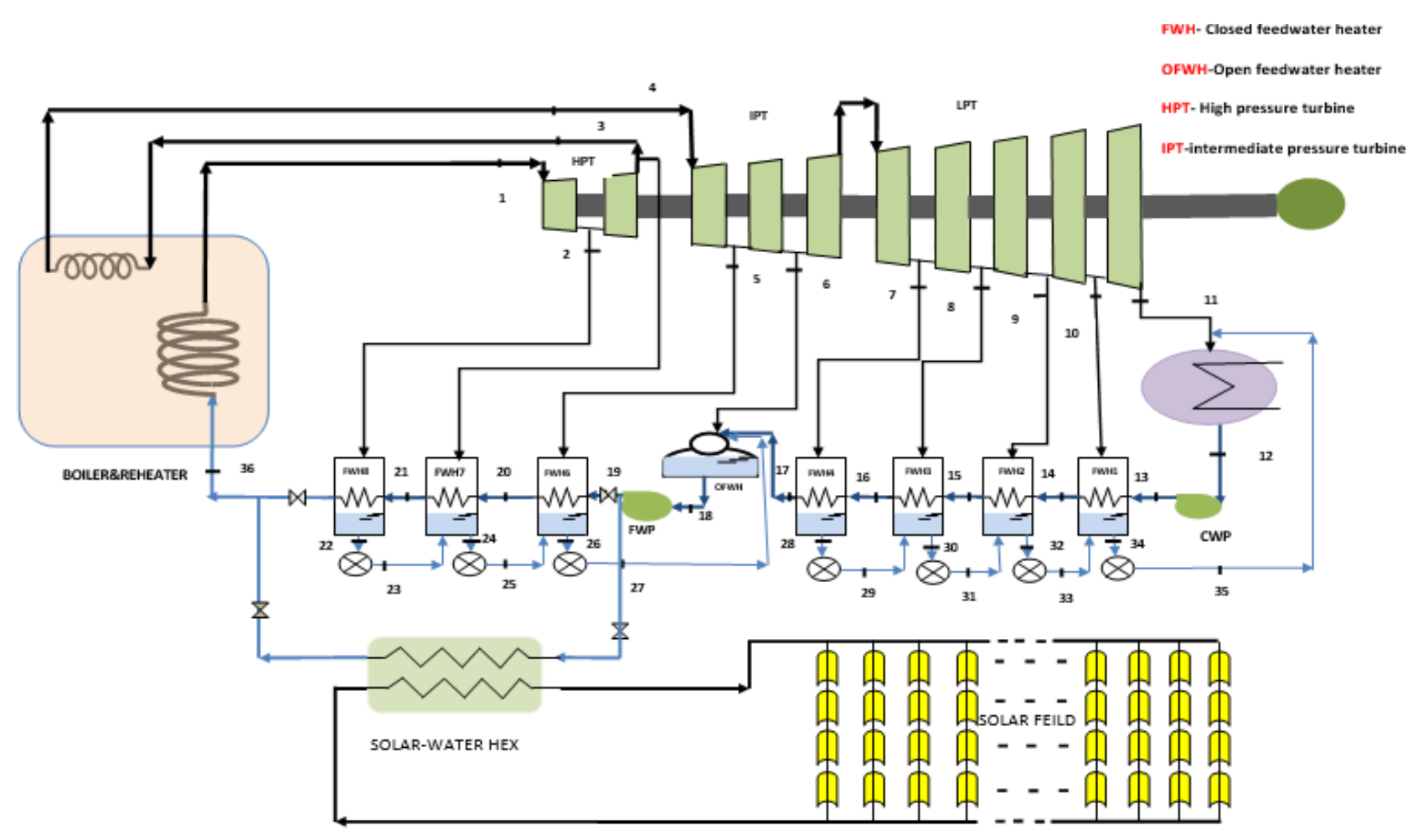

Figure 2. Schematics of proposed parabolic trough collector hybrid thermal power plant

In different schemes, Solar HEX is proposed to exchange heat from HTF (therminol VP1) to the water coming from FW pump in different ways.

In the first scheme, which is used for hot months such as March, April, May, June, July, August, September, and October, solar energy coming from the solar field is used for heating the steam before entering the boiler instead of using CFHs $(6,7,8)$. The second scheme uses steam heated by solar field instead of using CFH (8) which is used for cold months since the solar energy is low. Equations 3 and 4 are used to find the amount of solar energy required from the solar field in the first scheme and second scheme in $\mathrm{kW}$ respectively.

$$
\begin{aligned}
& \mathrm{Q}_{\text {solar }, 1}=\dot{\mathrm{m}}\left(\mathrm{h}_{36}-\mathrm{h}_{19}\right) \\
& \mathrm{Q}_{\text {solar }, 2}=\dot{\mathrm{m}}\left(\mathrm{h}_{36}-\mathrm{h}_{21}\right)
\end{aligned}
$$

Where $\dot{\mathrm{m}}$ is the mass flow rate of water in $\mathrm{kg} / \mathrm{s}$ and $\mathrm{h}$ are the enthalpies of water streams in $\mathrm{kJ} / \mathrm{kg}$. This selection of schemes is done considering the operation of preheaters depending on the amount of the solar energy collected from the solar field for each season as explained.

Calculations of the extraction steam percentages for Rankine Cycle power plant and for the different schemes of hybrid power plant are done and can be found in ref [14].

\subsection{Solar Energy Calculations}

Apparent Solar Time (AST) calculations with longitude correction are done then solar angles are calculated beforehand for a through solar energy analysis which are solar declination angle $(\boldsymbol{\delta})$, hour angle $(\mathrm{h})$, solar altitude angle $(\alpha)$, zenith angle $(\phi)$ and solar azimuth angle $(\mathrm{z})$, all in ${ }^{\circ}[6]$. After that, sun set and sun down times are calculated for different times of the year using formula where $\mathrm{L}$ is the local latitude, $H_{s s}$ represents the sunset time from local solar noon.

$$
\mathrm{H}_{\mathrm{ss}}=\frac{1}{15} \cos ^{-1}(\tan (\mathrm{L}) \tan (\delta))
$$

\subsubsection{Sun Tracking System Calculations}

The angle of incidence $(\boldsymbol{\theta})$ represents the angle between the sun rays and the normal of the collector surface and it is calculated with respect to the collector sun tracking system methodology [6].

Increasing the angle of incidence directly decreases the amount of the solar radiation so, tracking system is used to decrease the angle of incidence at all times. N-S horizontal axis with E-W tracking is proposed and following equation is used to find the incidence angle for this type of single-axis tracking [15].

$$
\cos (\theta)=\sqrt{\sin ^{2}(\alpha)+\cos ^{2}(\delta) \sin ^{2}(\mathrm{~h})}
$$

Equation 7 is used to find the slope of collector $(\beta)$; 


$$
\tan (\beta)=\tan (\phi)\left|\cos \left(Z_{s}-z\right)\right|
$$

Where $Z_{s}$ is the azimuth angle is either equal to (90) or ($90)$ that is depended on solar azimuth angle $(z)$;

$$
\text { If }(\mathrm{z})>0^{\circ} \text { degree, } \mathrm{Z}_{\mathrm{s}}=90^{\circ} ; \text { If }(\mathrm{z})<0^{\circ} \text { degree, } \mathrm{Z}_{\mathrm{s}}=-90^{\circ}
$$

\subsubsection{Hourly Beam Radiation Estimation}

Wassit power plant is located in Iraq, Wassit City where Longitude is $44.8^{\circ} \mathrm{N}$ and Latitude is $33.01^{\circ} \mathrm{E}$. Monthly average daily total radiation $(\mathrm{H})$ and monthly average daily total radiation on extraterrestrial horizontal surface $\left(\mathrm{H}_{0}\right)$ for July are $26.86 \mathrm{MJ} / \mathrm{m}^{2}$-day and 40.5 $\mathrm{MJ} / \mathrm{m}^{2}$-day respectively [16]. All other average daily radiation values are taken from this site.

The methodology used to find the average hourly beam radiation on tilted surfaces can be found in Appendix A.

\subsubsection{Characteristics of Proposed Parabolic Trough Collectors and Receivers}

Parabolic trough collectors used in the proposed study are chosen to be LS-3 [8] which is manufactured by Luz. company with a mirror reflectivity of 0.94, trough aperture of $5.76 \mathrm{~m}$, geometric concentration ratio of 26 , maximum working temperature of $390{ }^{\circ} \mathrm{C}, 545 \mathrm{~m}^{2}$ of mirror surface per collectors and overall length of $99 \mathrm{~m}$. The receivers are SCHOTT PTR70 which is manufactured by German with tube thermal conductivity of $15 \mathrm{~W} / \mathrm{m}$. K, solar absorbance of 0.96 , outer diameter od $0.125 \mathrm{~m}$ and length of $4.06 \mathrm{~m}$ per segment. (Schott Solar CSP GmbH, company presentation, 2014), [17].

\subsubsection{Thermal Analysis of Parabolic Trough Collectors}

For thermal analysis, 1 hour between 11:00-12:00 on $17^{\text {th }}$ of July (average day of July) is estimated to be the design point.

Assumptions for the thermal analysis of the collectors are as follows;

- To get accurate results, each collector is estimated to be divided into 24 segments for analytical calculations and computational simulation.

- Along each segment properties are constant. (Temperature of absorber, glass and mean fluid etc.)

- Flow is fully developed turbulent flow.

- Glass cover temperature $\left(\mathrm{T}_{\mathrm{g}}\right)$ is assumed close to the ambient temperature rather than the absorber temperature for the first iteration.

- Conduction is neglected at the ends of each trough and only radiation heat losses take place between the receiver and the glass in the annular vacuumed space.

- The mass flow rate of HTF for one row is estimated to be equal to $5 \mathrm{~kg} / \mathrm{s}$, [18].
The formulations used to find useful energy for one segment are shown below [6], [15].

$$
\begin{aligned}
\mathrm{T}_{\mathrm{fm}} & =\frac{\mathrm{T}_{\mathrm{i}}+\mathrm{T}_{0}}{2} \\
\mathrm{U}_{\mathrm{f}} & =\frac{\dot{\mathrm{m}}_{\mathrm{f}}}{\rho \mathrm{A}_{\mathrm{i}}}
\end{aligned}
$$

where; $\dot{\mathrm{m}}_{\mathrm{f}}$ is the mass flow rate of HTF, $A_{i}$ is the inner area of the receiver and $\rho$ is the density of HTF at average HTF temperature, $\mathrm{T}_{\mathrm{fm}}$.

Reynold number and Prandtl number are calculated as;

$$
\begin{gathered}
\mathrm{R}_{\mathrm{eD}}=\frac{\mathrm{U}_{\mathrm{f}} \mathrm{D}_{\mathrm{i}}}{\mu} \\
\mathrm{p}_{\mathrm{r}}=\frac{\mu \mathrm{c}_{\mathrm{p}}}{\mathrm{k}}
\end{gathered}
$$

Where; $\mu$ is the viscosity of HTF at $\mathrm{T}_{\mathrm{fm}}, \mathrm{c}_{\mathrm{p}}$ and $\mathrm{k}$ are the heat capacity and thermal conductivity of HTF at $\mathrm{T}_{\text {fm }}$ respectively. The flow is estimated to be fully developed turbulent flow.

If $R_{e D}>10^{4}, 0.6<p_{r}<160$, and $L / D>10$, DittusBoelter correlation for the flow inside the pipe with heating processes can be used to find Nusselt number and heat transfer coefficient, [19] such as;

$$
\begin{gathered}
\mathrm{N}_{\mathrm{UD}}=0.023\left(\mathrm{R}_{\mathrm{eD}}^{\frac{4}{5}}\right)\left(\mathrm{p}_{\mathrm{r}}^{0.4}\right) \\
\mathrm{h}_{\mathrm{i}}=\frac{\mathrm{N}_{\mathrm{UD}} \mathrm{D}_{\mathrm{i}}}{\mathrm{k}}
\end{gathered}
$$

The temperature gradients along the receiver is small, so the receiver temperature is assumed to be constant. An iterative procedure is applied to find the overall heat transfer coefficient starting by first assuming a value of glass temperature close to ambient temperature at design point rather than the absorber temperature and iterating it. The iterative method can be found in Appendix B.

\subsubsection{Sizing the Solar Field, HEX and the Energy Gain Calculations}

A typical PTC field is composed of a number of parallel rows each row composed of several collectors which are connected in series. The following equation is used to find the number of collectors in one row $(\mathrm{N})$ as [10];

$$
N=\frac{\Delta \mathrm{T}}{\Delta \mathrm{Tc}}
$$

Where $\Delta \mathrm{T}$ is the difference between the outlet temperature and inlet temperature of HTF in one row and $\Delta \mathrm{Tc}$ is the difference between the inlet and outlet temperature for HTF among one collector.

The number of rows in the solar field represents the ratio of the energy needed from the industrial process to the energy collected from one row of collectors at design point. To be on the safe side, while sizing solar field, a solar multiple is used which is the ratio of the output 
energy from solar field to the energy demand at the design point. For solar power plants without heat storage tanks, it is used in the range of 1.14 to 1.3 [18].

The overall energy gain from the solar field is obtained by using the formula below;

$$
\mathrm{Q}_{\mathrm{u}, \text { all }}=\left(\mathrm{q}_{\mathrm{u} 1}+\mathrm{q}_{\mathrm{u} 2}+\mathrm{q}_{\mathrm{u} 3}+\mathrm{q}_{\mathrm{u} 4}\right) \mathrm{N}_{\text {rows }}
$$

Where $\mathrm{q}_{\mathrm{u} 1}, \mathrm{q}_{\mathrm{u} 2}, \mathrm{q}_{\mathrm{u} 3}$ and $\mathrm{q}_{\mathrm{u} 4}$ are the energy gain from collector 1 to 4 respectively and $\mathrm{N}_{\text {rows }}$ is the number of rows in solar field.

The mass flow rate of HTF VP1 ( $\left.\dot{\mathrm{m}}_{\mathrm{VP} 1}\right)$ is found by using the formula below;

$$
\dot{\mathrm{m}}_{\mathrm{VP} 1}=\dot{\mathrm{m}}_{\mathrm{VP} 1 \text {,row }} \cdot \mathrm{N}_{\text {rows }}
$$

Where $\dot{m}_{V P 1 \text {, row }}$ is mass flow rate of HTF for one row, which is assumed to be equal to $5 \mathrm{~kg} / \mathrm{s}$ [18].

After the design of the solar field, with the data from the hybrid power plant, design calculations of solar-water heat exchanger are conducted. Assumptions done for this design process are as follows, [9].

- The outer surface of the heat exchanger is adiabatic.

- The pressure drops for both water and heat transfer fluid in heat exchanger are negligible;

- The heat exchanger operates in steady state.

- There is no heat generation in HTF

As the heat transfer fluid, therminol VP1 is chosen since operation pressure is high to avoid evaporation risk. Design temperatures and pressures for the water is 165 bar and $170^{\circ} \mathrm{C}$ at the inlet of the HEX from the tube side and $280^{\circ} \mathrm{C}$ at the outlet. The heat transfer fluid with temperature equal to $310^{\circ} \mathrm{C}$ enters the shell and exits the HEX at temperature equal to $200^{\circ} \mathrm{C}$. The total heat transfer required for the heat exchangers and the outlet temperature are as follows;

$$
\begin{gathered}
\mathrm{Q}_{\text {solar }}=\dot{\mathrm{m}}\left(\mathrm{h}_{36}-\mathrm{h}_{19}\right) \\
\dot{\mathrm{m}}\left(\mathrm{h}_{36}-\mathrm{h}_{19}\right)=\dot{\mathrm{m}}_{\mathrm{f}} \mathrm{cp}\left(\mathrm{T}_{\mathrm{i}}-\mathrm{T}_{0}\right) \\
T_{0}=\mathrm{T}_{\mathrm{i}}-\frac{\dot{\mathrm{m}}\left(\mathrm{h}_{36}-\mathrm{h}_{19}\right)}{\dot{\mathrm{m}}_{\mathrm{f}} \mathrm{cp}}
\end{gathered}
$$

The values of $\mathrm{T}_{\mathrm{i}}$ and $\mathrm{T}_{0}$ are the inlet and outlet heat transfer fluid temperature.

Since there is a need of very high amount of energy from the solar field, sizing was determined after many trails. Eight heat exchangers are designed to transfer the energy from solar radiation to the water comes from feed-water pump by using heat transfer fluid VP1. These heat exchangers are constructed in series. Details of the HEX preliminary design and the verification procedure can be found in ref. [14] with respect to ASME B31.3 standards [20] and TEMA standards [21].

\subsection{Computational Analysis}

\subsubsection{MATLAB Simulation of Rankine Cycle Power Plant}

All thermodynamic and heat balance equations are used in MATLAB simulation to find the values of enthalpy, entropy, fractions of extraction steam, specific pump works and specific turbine works, heat added in the boiler, fuel consumption, mass flow rate of working fluid, power plant efficiency and heat extracted from condenser. and verification is done by using data of Wassit thermal power plant.

The Rankine Cycle power plant simulation on SIMULINK is shown in Figure 3.

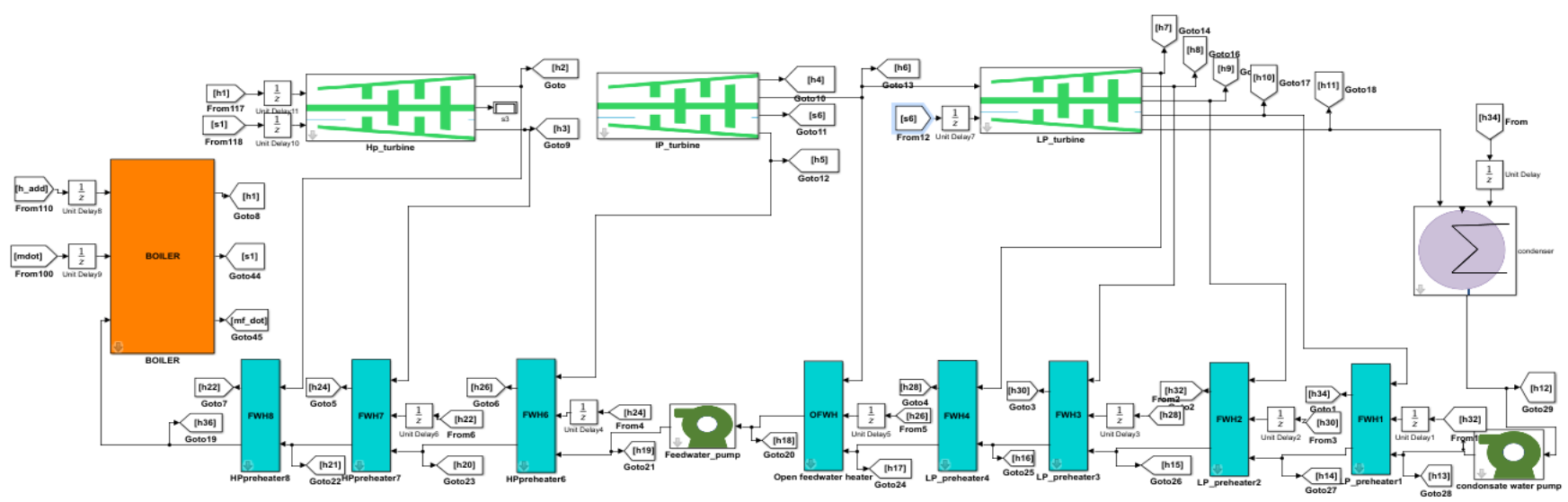

Figure 3. Rankine Cycle thermal power plant simulation with MATLAB SIMULINK

\subsubsection{MATLAB Simulation of Hybrid Power Plant}

All relevant values for the Rankine Cycle power plant are used or modified to calculate the hybrid energy generation. Modeling is done in two schemes, one for hot months, one for cold months as explained in part 2.2. before.

The simulations for different schemes are shown in Figures 4 and 5 respectively. 


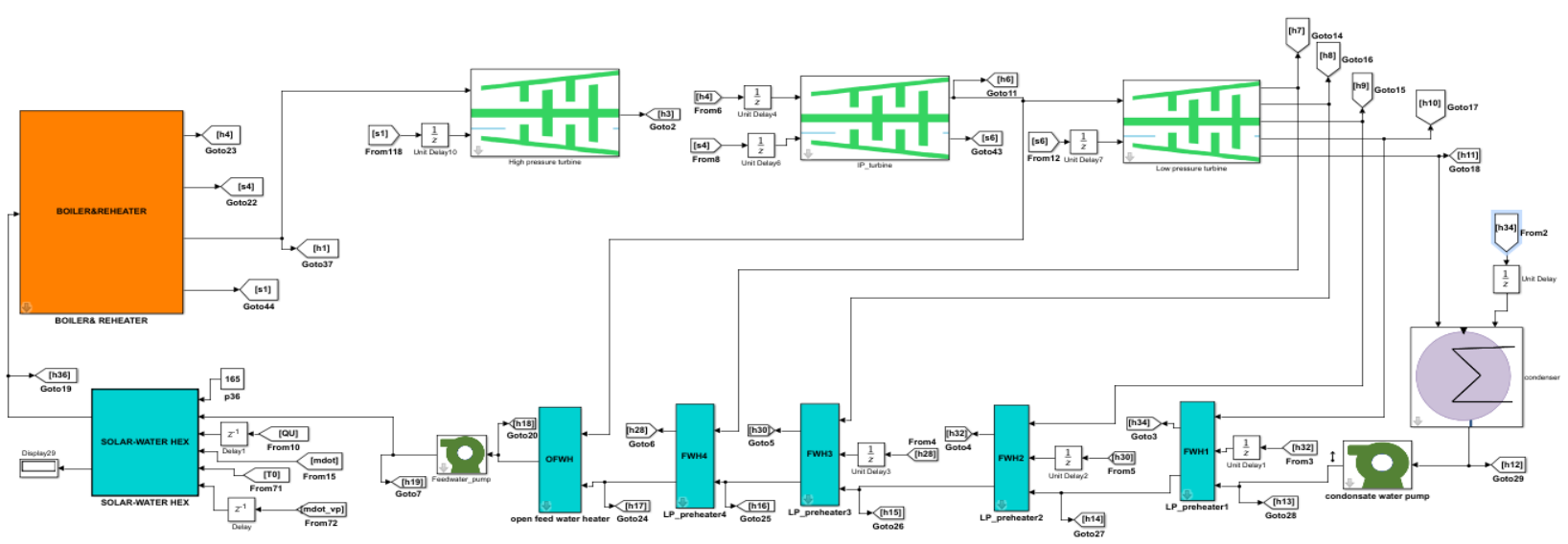

Figure 4. Hybrid power plant simulation with MATLAB SIMULINK for first scheme

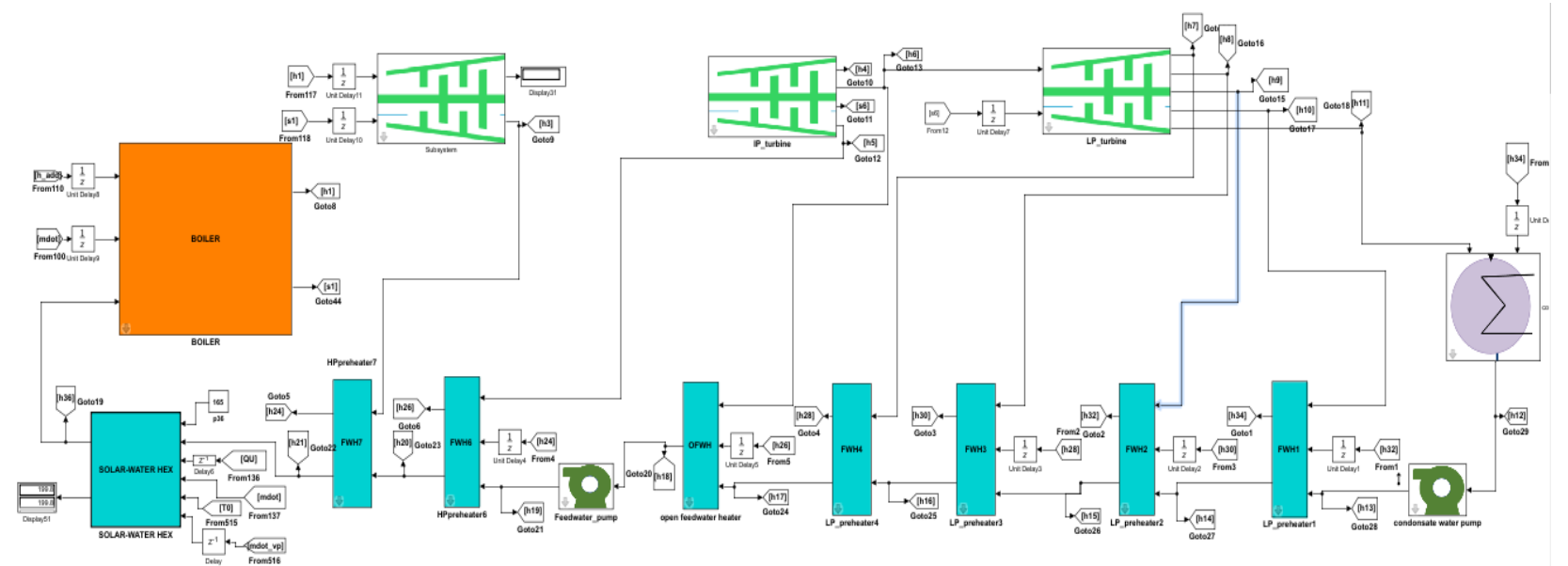

Figure 5. Hybrid power plant simulation with MATLAB SIMULINK for second scheme

For both schemes, there are two modes of operation describing the two cases of simulation: 1- Boosting power mode and 2- Saving fuel mode. Boosting power mode simulation is used to find the electricity generation, mass flow rate of working fluid, power plant efficiency etc. by making the boiler work with the same fuel consumption of Rankine Cycle power plant which is 70 tons/h, aimed to increase the output power. Saving fuel simulation is used to find the mass flow rate of heavy fuel oil, power plant

\subsection{Economic Analysis- Levelized Cost of Energy (LCOE) Calculation}

LCOE is used to estimate the cost of renewable energy from hybrid power plant in terms of $\$ / \mathrm{kWh}$ by considering projects life. It allows comparison of different methods of electricity generation (fossil fuel/ renewable/ hybrid electric generation) on a consistent basis. LCOE which can be regarded as the average minimum price at which electricity must be sold in order to start profiting over the lifetime of the project is found by using the following formula [11];

$$
\mathrm{LCOE}=\frac{\mathrm{I}+\sum_{\mathrm{n}=1}^{\mathrm{N}}\left[\frac{\text { Cost }_{\text {annual, }}}{(1+\mathrm{d})^{\mathrm{n}}}\right] *\left(1-\mathrm{T}_{\mathrm{R}}\right)}{\sum_{\mathrm{n}=1}^{\mathrm{N}} \dot{\mathrm{E}}_{\text {annual }}\left(1-\mathrm{R}_{\mathrm{d}}\right)^{\mathrm{n}} /(1+\mathrm{d})^{\mathrm{n}}}
$$

efficiency ...etc. by keeping the output power as the same as the Rankine cycle thermal power plant (330 MW) to see how much fuel can be saved for the same amount of power production with the help of the solar field. Simulations are done for three different days $\left(17^{\text {th }}\right.$ July, $15^{\text {th }}$ April and $17^{\text {th }}$ January) which represents the summer, fall and autumn, and winter respectively. Each simulation is done for one hour period, assuming system acts steady during that hour.

Where I is the initial investment cost, Cost $_{\text {annual,n }}$ is annual fuel, operation and maintenance (O\&M) cost, $d$ is the discount rate, $T_{R}$ is the tax rate which is estimated to be equal to $15 \%, \mathrm{R}_{\mathrm{d}}$ is system degradation rate, $\dot{\mathrm{E}}_{\text {annual }}$ is the net annual output power in $\mathrm{kWh}, \mathrm{N}$ is the project life.

The estimated cost that is used to find the LCOE is adapted from the studies [22], [23] which depend on Solar Advisor Model (SAM) model using the parameters in Table 1.

Table 1 . The estimated cost that are used to calculate LCOE [22], [23] 


\begin{tabular}{|c|c|c|}
\hline Direct Cost (DC) & Value & Unit \\
\hline Site Improvements & 25 & $\$ / \mathrm{m}^{2}$ \\
\hline Solar Field & 295 & $\$ / \mathrm{m}^{2}$ \\
\hline HTF System & 90 & $\$ / m^{2}$ \\
\hline Fossil Backup & 0 & $\$ / \mathrm{kW}$ \\
\hline Contingency & 10 & $\%$ of DC \\
\hline \multicolumn{3}{|l|}{ Indirect Costs } \\
\hline $\begin{array}{l}\text { Engineer, } \\
\text { Construct }\end{array}$ & 15 & $\%$ of DC \\
\hline Project, Land, Management & 3.5 & $\%$ of DC \\
\hline Sales Tax & 7.75 & $\%$ \\
\hline HEX COST* & $12990 \times 8$ & $\$$ \\
\hline \multicolumn{3}{|l|}{ 0\&M Cost: } \\
\hline Fixed Annual Cost & 0 & $\$ / y r$ \\
\hline Fixed Cost by Capacity & 70 & $\$ / \mathrm{kW}-\mathrm{yr}$ \\
\hline Fuel Cost & 0 & $\$ / M M B T U$ \\
\hline \multicolumn{3}{|l|}{ Other Costs } \\
\hline Project Life & 30 & years \\
\hline Annual Degradation Rate & 0.5 & $\%$ \\
\hline Inflation Rate & 2.5 & $\%$ \\
\hline $\begin{array}{lll}\text { Variable } & \text { Cost } & \text { per } \\
\text { Generation } & & \end{array}$ & 3 & $\$ / M W h$ \\
\hline
\end{tabular}

Using the parameters from Table 1, direct cost, indirect cost and annual cost are calculated as below, to find the LCOE.

$$
\begin{aligned}
\mathrm{DC}=[(\mathrm{SI}+\mathrm{SF}+ & \left.\mathrm{HTF}_{\text {system }}\right) \mathrm{A}_{\mathrm{sf}}+\mathrm{HEX}_{\text {cost }} \\
& \left.+\mathrm{C}_{\text {storage }}+\mathrm{C}_{\mathrm{FB}}+\mathrm{C}_{\mathrm{PB}}\right](1 \\
& \left.+\mathrm{F}_{\text {contingency }}\right)
\end{aligned}
$$

Where DC is the direct cost, SI is the site improvement cost, $\mathrm{SF}$ is the solar field cost, $\mathrm{HTF}_{\text {system }}$ is the cost of heat transfer fluid, $\mathrm{A}_{\mathrm{sf}}$ is the area of solar field, $\mathrm{HEX}_{\text {cost }}$ is the heat exchangers cost [14], $C_{\text {storage }}$ is the cost of the storage tank of HTF, $\mathrm{C}_{\mathrm{FB}}$ is the cost of fossil fuel back-up, $\mathrm{C}_{\mathrm{PB}}$ is the cost of the power block, $F_{\text {contingency }}$ is the contingency factor.

The indirect cost (IC) can be found as below;

$$
\mathrm{IC}=\mathrm{DC}(\mathrm{EPC}+\mathrm{PLM}+\mathrm{ST})
$$

Where EPC is total of engineering, procurement and construction costs, ST is the sale tax and PLM is the total of project, land, management cost.

the annual cost is found by using the following formula;

$$
\begin{aligned}
\text { Cost }_{\text {annual, } \mathrm{n}}=\mathrm{FC} & +(\mathrm{FCC}) \mathrm{P}_{\text {nom }} \\
& +(\mathrm{VCG}) \dot{\mathrm{E}}_{\text {annual }}(\mathrm{MWh}) \\
& +\mathrm{C}_{\text {fuel }}
\end{aligned}
$$

Where FC is the fixed annual cost, FCC is the fixed cost by capacity, VCG is the variable cost per generation, $\mathrm{C}_{\text {fuel }}$ is the fuel cost.

\section{Results and Discussion}

Results related to solar field calculations, temperatures vales of HFT, output power, amount of fuel saving and efficiency values are given in the following parts.

\subsection{Amount of Solar Radiation}

Figure $6 \mathrm{a}$ and $\mathrm{b}$, shows the amount of average hourly beam radiation and the incidence angles in July, April and January respectively.

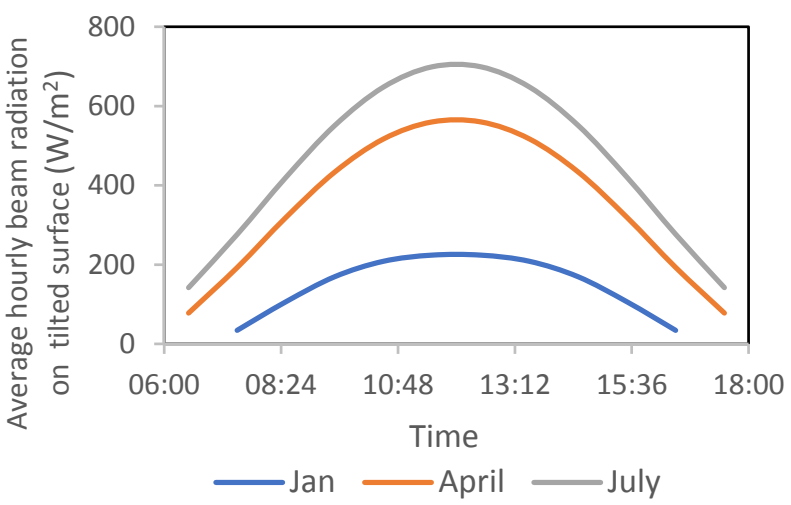

(a)

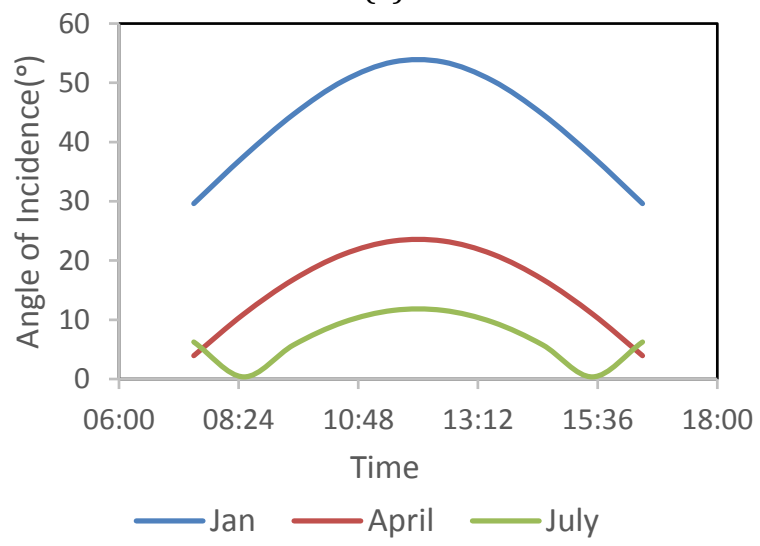

(b)

Figure 6 a- Hourly beam radiation on tilted surface $\left(\mathrm{G}_{\mathrm{BT}}\right)$ and b- Incidence angles for January, April and July

When the calculated values are examined, it can be seen that, solar power is highest in July, lowest in January and the incidence angles are maximum in January and minimum in June as expected. This has the biggest effect on the energy gained from the solar field.

\subsection{Result of the Solar Field and HEX Calculations}

The parameters regarding solar field design and preliminary design of the solar-water HEX are shown in Table 2 and 3 respectively.

Table 2. Results of solar field design

\begin{tabular}{|ll|}
\hline Properties & Value \\
\hline \hline Number of collectors in a row & 4 \\
Number of rows & 154 \\
Estimated solar multiple & 1.3 \\
Total aperture area $\left(\mathrm{m}^{2}\right)$ & 351267.8 \\
Total area of the solar field $\left(\mathrm{m}^{2}\right)$ & 1387995 \\
\hline
\end{tabular}


Table 3. Results of HEX preliminary design [14]

\begin{tabular}{|c|c|}
\hline Properties & Values \\
\hline HEX Type & E shell and tube \\
\hline Number of heat exchangers & 8 \\
\hline The pipe material & ASTM A691 1Cr \\
\hline Output diameter of the pipe & $26.7 \mathrm{~mm}$ \\
\hline Input diameter of the pipe & $15.58 \mathrm{~mm}$ \\
\hline The length of the pipe & $6 \mathrm{~m}$ \\
\hline Inside shell diameter & $1.52 \mathrm{~m}$ \\
\hline $\begin{array}{l}\text { Number of tubes in the heat } \\
\text { exchanger }\end{array}$ & 1515 \\
\hline $\begin{array}{l}\text { Amount of pressure drop in } \\
\text { shell side at design point }\end{array}$ & $0.9 \mathrm{bar}$ \\
\hline $\begin{array}{l}\text { Amount of pressure drop in tube } \\
\text { side at design point }\end{array}$ & 0.41 bar \\
\hline Overall heat transfer coefficient & $821.9 \mathrm{~W} / \mathrm{m}^{2} \mathrm{~K}$ \\
\hline
\end{tabular}

\subsection{Useful Energy Collected Among the Collector Rows}

Energy collected from one row (one row has 4 collectors each one contains 24 segments) of solar collectors from the solar field is observed and the instantaneous energy gain (thermal power) from each row of the solar field at solar noon for full capacity, for the average days in July, April and January are calculated. In July, instantaneous thermal power of one segment is about $12500 \mathrm{~W}$. In April and January, this value drops to an average of $9800 \mathrm{~W}$ and $3700 \mathrm{~W}$ respectively. Also when examined, energy gain in the first segments of the collector rows are higher than the energy gain from the following segments in the same hour because the HTF temperature and receiver temperature gets higher which increases radiation losses for same amount of solar radiation.

\subsection{Temperature Distribution Among the Collector Rows}

HTF output temperature for one row of the solar field at solar noon for full capacity are simulated to be $307^{\circ} \mathrm{C}$, $278^{\circ} \mathrm{C}$ and $215^{\circ} \mathrm{C}$ for July, April and January respectively. When the glass cover temperature is examined, same trend is seen with average of $325 \mathrm{~K}$ in July, $310 \mathrm{~K}$ in April and $295 \mathrm{~K}$ in January.

\subsection{Overall Heat Loss Coefficient Among the Collector Rows}

Figure 7 shows the calculated values for heat loss coefficient $\mathrm{UL}\left(\mathrm{W} / \mathrm{m}^{2} \mathrm{~K}\right)$ for each segment for one row of solar field at solar noon for full capacity for July, April and January respectively.

Heat loss coefficient depends on many parameters such as; ambient temperature, wind velocity, glass cover temperature, radiation coefficient between the glass envelope and the surrounding and the radiation coefficient between the receiver absorber and glass envelope which depends on the absorber temperature, absorber emissivity, and glass temperature

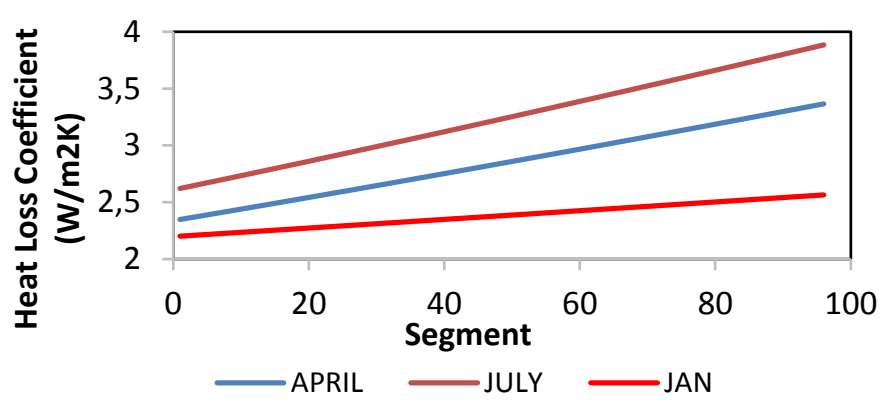

Figure 7. Heat Loss coefficient (UL) for every segment for July, April and January.

For the reasons mentioned above, the overall heat loss coefficient is lowest in January and highest in July with average values of $2.25 \mathrm{~W} / \mathrm{m}^{2} \mathrm{~K}$ and $3.12 \mathrm{~W} / \mathrm{m}^{2} \mathrm{~K}$.

\subsection{Output Power of the Power Plant: Boosting Power Simulation}

By the proposed hybrid power plant, output power increases depending on the date and the time of the year as can be seen in Figure 8 below.

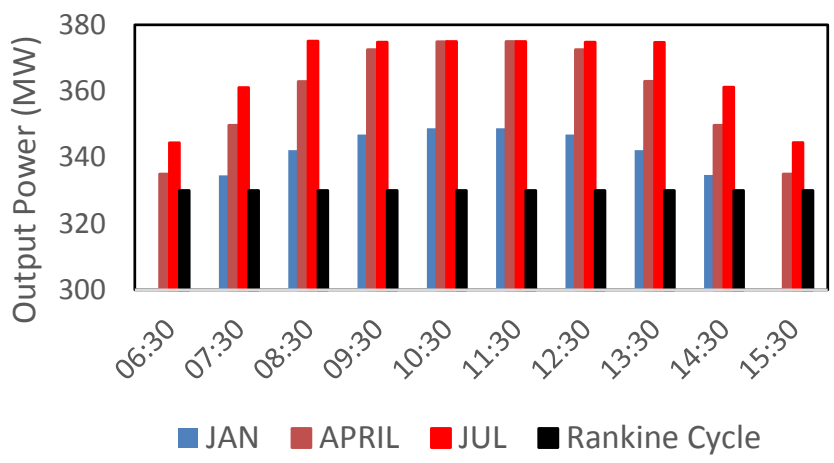

Figure 8. Total power of the plant for different months (with and without collector field)

The output power of the Rankine cycle and the hybrid power plant for the average days of January, April and July for boosting power mode are shown in Figure 8. As seen in this figure, the maximum output power is obtained in July, for the same amount of fuel input, as can be predicted. It should also be noticed that, the output energy in midday hours in July and April are approximately same because the utilization of energy from solar field is constant since less number solar collectors are proposed to be operated during hot summer days.

\subsection{Total Fuel Consumption of the Power Plant: Saving Fuel Simulation}

One of the most important purposes of the proposed power plant is decreasing the fuel consumption, which is studied by saving fuel simulations. The fuel consumptions in saving fuel mode in the proposed hybrid power plant for the average days of January, April and July are shown in Figure 9. The amount of fuel consumption for the first and last hours are higher since the amount of energy gain from the solar field are the 
lowest and the boiler compensates for this deficit of energy by fuel oil combustion.

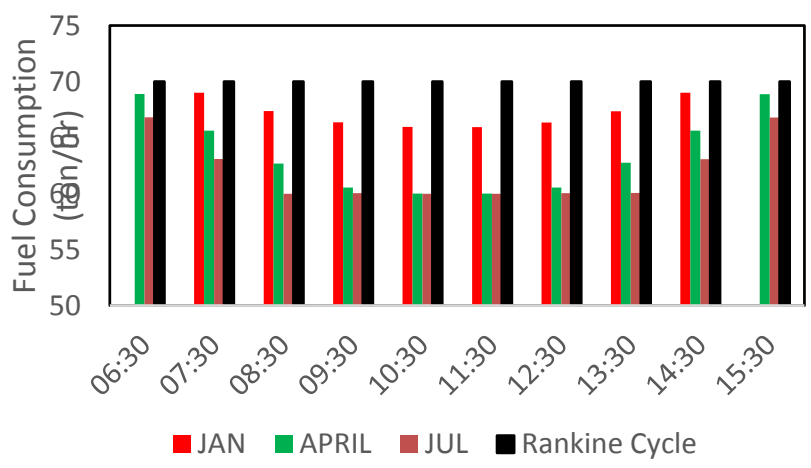

Figure 9. Comparison of total fuel consumption of the plant for different months (fuel saving mode)

\subsection{Efficiency of the Power Plant}

Figure 10 shows the comparison between the efficiencies of the Rankine Cycle power plant and the proposed hybrid thermal power plant in saving fuel mode for the average days of January, April and July respectively.

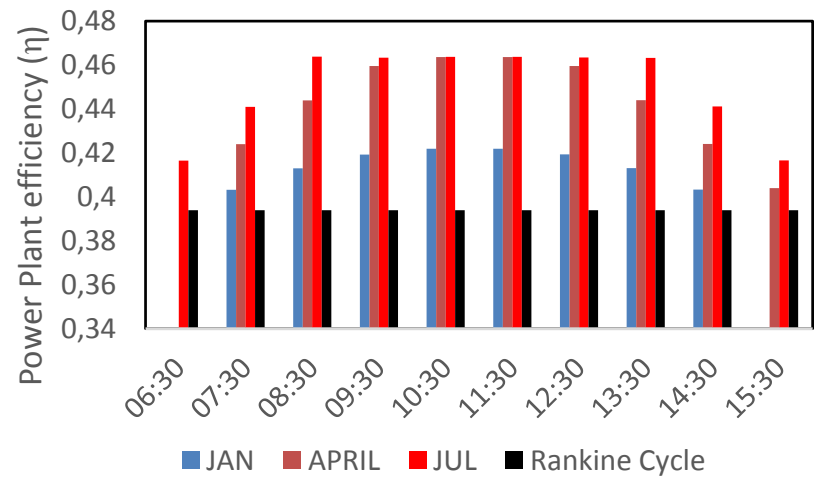

Figure 10. Comparison of the efficiency in saving fuel mode for Rankine Cycle thermal power plant and the proposed hybrid power plant

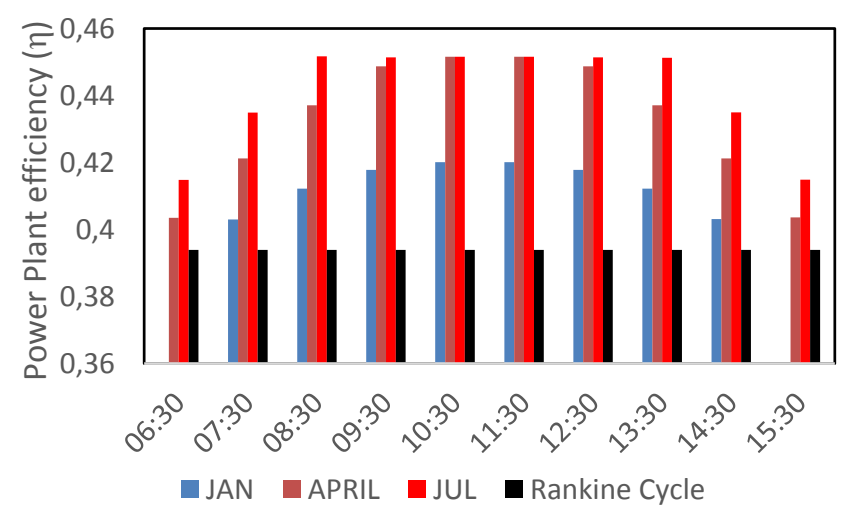

Figure 11. Comparison of the efficiency in boosting power mode for Rankine Cycle thermal power plant and the proposed hybrid power plant

On the other hand, the comparison between efficiency values in boosting power mode is shown in Figure 11.
As shown in both figures, the efficiency is increased in both modes. For saving fuel mode, the amount of energy added to the working fluid in the boiler is lower than in the Rankine Cycle power plant. For the boosting power mode, the efficiency of proposed hybrid power plant is raised since the same amount of fuel is used compared to the Rankine Cycle power plant with a higher output power.

\section{Conclusion}

In this study, thermodynamic analysis and simulation of a steam turbine power plant hybrid with parabolic trough solar collector field is done. For the study, first, thermodynamic analysis of the power plant is done, after completing the analytical calculations, numerical modelling and validation of the results, a design process including selection of the heat transfer fluid (HTF), determination of the required solar power, orientation and sizing of the solar field, preliminary design of the solar heat exchanger (HEX) and other relevant auxiliary equipment are conducted. Finally, thermodynamic analysis of the hybrid plant is performed.

Simulation of steam power plant with MATLAB SIMULINK is done using real data from one unit of Wassit thermal power plant, in Wassit, Iraq for verification of the models. Simulations are carried out with the designed solar hybrid version of this power plant and the results are compared with the original power plant in terms of increasing output electricity (mode 1) and saving fuel oil (mode 2) considering the efficiency improvement and the environmental effects.

For the design of solar field, important solar field parameters like heat transfer fluid output temperature, glass and absorber temperatures, overall heat loss coefficient and useful output power of the collectors are simulated and discussed.

Studies showed that, proposed hybrid power plant efficiency is higher for both modes, the output power is increased for the first mode and a considerable amount of fuel and water is saved for the second mode which are discussed in the following paragraphs.

The efficiency of the proposed hybrid power plant is found to be higher than the Rankine Cycle alone in both fuel saving mode and boosting power mode as expected. The average value of efficiency increases during day time in January, April, and July in saving fuel mode are $2 \%, 4.4$ $\%$ and $5.5 \%$ respectively, while in boosting power mode efficiency increases $1.9 \%, 3.7 \%$, and $4.6 \%$ when compared to Rankine cycle respectively.

The annual increase of the power produced in boosting power mode is equal to $98.4 \mathrm{GWh}$. This is an important amount to be used to cope on electricity deficiency.

The annual decrease in the heavy fuel oil consumption in saving fuel mode is 24120 tons (almost $4 \%$ of annual fuel consumption) which is a very big amount considering the reverse effects of burning fossil fuel on the environment. 
Another important advantage of the hybrid thermal power plant is conservation of water. The amount of water (steam to be produced in the boiler) that is used to generate the same power in hybrid manner is decreased. The annual amount of water saved is about 435210 tons for saving fuel mode and in boosting power mode water saving amount is about 176320 tons annually, which are considerable amounts since environmental impact is important.

Simple economic analysis is performed and found that $\mathrm{LCOE}$ is equal to $13.9 \mathrm{cent} / \mathrm{kWh}$ and this price is competitive comparing with electricity production of other kinds of renewable or hybrid energy power plants which are: between 7-15 cent/kWh for PV, biogas and wind, 10-22 cent/kWh for GT systems, 12- 20 cent/kWh for solar thermal and 9-16 cent/kWh for coal fired power plants [24]. LCOE can also be a useful method for finding optimum size of the solar field for hybrid or solar only power plants for the best or improved performance.

The study suggests that, integrating parabolic trough collectors with existing thermal power plant is a sensible choice to increase efficiency, reliability and decrease environmental problems and the orientation of the hybrid connection plays an important role on these parameters. This study can also be a guide for good utilization of hybrid solar energy in countries where there is a deficit of electricity production, degrading fossil fuel resources and still very limited utilization of solar energy.

\section{List of References}

[1] The International Energy Outlook [IEO], U.S. Department of Energy, Washington, 2016. Retrieved December 3, from http://large.stanford.edu/courses/2010/ph240/riley2/docs EIA-0484-2010.pdf.

[2] Bakos,G.,C. and Tsechelidou, C. "Solar aided power generation of a 300 MW lignite fired power plant combined with line-focus parabolic trough collectors field", Renewable Energy, 60, 540-547, 2013

[3] Zhao,Y., Hong, H. and Jin, H., "Optimization of the solar field size for the solar-coal hybrid system", Applied Energy, 185, 1162-1172, 2017

[4] Sargent, Lundy, “Assessment of Parabolic Trough and Power Tower Solar Technology Cost and Performance Forecasts". NREL-report, Colorado, USA. Retrieved September $\quad 14$ 2003, from https://www.nrel.gov/docs/fy04osti/34440.pdf.

[5] Chandra, L., and Dixit, A., Concentrated Solar Thermal Energy Technology, Springer Nature Singapore Pte Ltd., 2018

[6] Kalogirou, S., A., Solar Energy Engineering (processes and systems), Elsevier Inc., , USA, 2009

[7] Peng, S., Hong, H., Jin, H., Zhang, Z., "A new rotatableaxis tracking solar parabolic-trough collector for solarhybrid coal-fired power plants", Solar Energy, 98, 492502,2013

[8] Goswami, D., Y., and Kreith, F., Energy Conversion, CRC press, USA, 2008
[9] Kakaç, S., Liu, H., Pramuanjaroenkij, A. Heat Exchanger Selection, Rating, and Thermal Design, third edition. CRC Press, 2012

[10] Li, J., Yu, X., Wang, J., \& Huang, S. "Coupling performance analysis of a solar aided coal-fired power plant", Applied Thermal Engineering, 106, 613-624, 2016

[11] Eva Bernardos, Ignacio López, Javier Rodríguez, Alberto Abánades, "Assessing the potential of hybrid fossil-solar thermal plants for energy policy making: Brayton cycles" Energy Policy, 62, 99-106, 2013

[12] El-Wakil, M., M., Power Plant Technology, McGrawHill Inc., University of Wisconsin, 1984

[13] Moran, M., J., \& Shapiro, H., N., Fundamentals of Engineering Thermodynamics, 5th Edition, John Wiley and Sons Ltd, England, 2004

[14] Al-Attwani, A., H., S., Thermodynamic analysis and simulation of parabolic trough solar collector hybrid steam turbine power plant, MSc Thesis Submitted to Çankaya University, Mechanical Eng. Dept., 2017

[15] Duffie, J., A., Beckman, W., A., Solar Engineering of Thermal Processes, Fourth Edition. John Wiley \& Sons, Inc., 2013

[16] Online meteorological data in Iraq, Retrieved December 1, 2017, from http://www.agromet.gov.iq/index.php?name=Pages\&op=p age\&pid=157.

[17] Men, W., Optical and thermal modeling of parabolic trough concentrator systems, 'PhD dissertation submitted to ETH ZURICH', retrieved December 1, 2017, from http://doi.org/10.3929/ethz-a-010120400

[18] Lovegrove, K., and Stein, W., Concentrating solar power technology, principle, Woodhead Publishing, England 2012

[19] Incropera, F., P., Dewitt, D., P., Therodore, and Bergman, T., L., Lavine, A., S, Fundamentals of Heat and Mass Transfer, 5th edition, WILY\& Sons, Inc., 2013

[20] American Society of Mechanical Engineers (ASME), ASME B31.1-2002, American National Standard, ASME Code for Pressure Piping,2004

[21] Standards of the Tubular Exchanger Manufactures Association, TEMA Standards, 2017

[22] Padilla, R., V., Simplified Methodology for Designing Parabolic Trough Solar Power Plants. PhD. Dissertation submitted to University of South Florida, retrieved December 14, 2017, from https://scholarcommons.usf.edu/cgi/viewcontent.cgi?ref erer $=\&$ httpsredir $=1 \&$ article $=4585 \&$ context $=$ etd

[23] Blair, N., Mehos, M., and Christensen, Sensitivity of Concentrating Solar Power trough performance, cost, and financing with the Solar Advisor Model. Tech. Rep. NREL/CD-550-42709, NREL, 2008.

[24] U.S. Energy Information Administration, Levelized Cost and Levelized Avoided Cost of New Generation Resources in the Annual Energy Outlook, 2019 


\section{Appendix A}

The methodology to find the average hourly beam radiation on the tilted surface.

Following method is used to find hourly beam radiation, [6]. The monthly average index clearance $\left(\mathrm{K}_{\mathrm{T}}\right)$ is;

$$
\mathrm{K}_{\mathrm{T}}=\frac{\mathrm{H}}{\mathrm{H}_{0}}
$$

Below is the empirical equation that is used to find the average diffuse radiation;

$$
\frac{\mathrm{H}}{\mathrm{H}_{\mathrm{D}}}=1.39-4.027 \mathrm{~K}_{\mathrm{T}}+5.531 \mathrm{~K}_{\mathrm{T}}{ }^{2}-3.108 \mathrm{~K}_{\mathrm{T}}{ }^{3}
$$

$\mathrm{H}_{\mathrm{D}}$ is monthly average diffuse radiation on the terrestrial horizontal surface. Lui and Jordan (1977) correlation is used to find the ratio of hourly diffuse radiation to the daily diffuse radiation $\left(r_{d}\right)$ as;

$$
r_{d}=\left(\frac{\pi}{24}\right) \frac{\cos (h)-\cos \left(h_{s s}\right)}{\sin \left(h_{s s}\right)-\left(\frac{2 \pi h_{s s}}{360}\right) \cos \left(h_{s s}\right)}
$$

The Collares-Pereira and Rabl (1977) correlation that is used to find the ratio of hourly total radiation to the daily total radiation is $(r)$ is;

$$
r=\left(\frac{\pi}{24}\right)\left[\alpha+\beta \cos \left(h_{s s}\right)\right]\left(\frac{\cos (h)-\cos \left(h_{s s}\right)}{\sin \left(h_{s S}\right)-\left(\frac{2 \pi h_{s S}}{360}\right) \cos \left(h_{s S}\right)}\right)
$$

With $\alpha=0.409+0.5016 \sin \left(\mathrm{h}_{\mathrm{ss}}-60\right)$, and

$$
\begin{aligned}
\beta=0.6609-0.4767 \sin ( & \left.h_{s s}-60\right) \text { and: } \\
H & =H_{D}+G_{B n} \\
G_{B T} & =G_{B n} \cos (\theta)
\end{aligned}
$$

where; $G_{B n}$ is the direct beam radiation and $G_{B T}$ is the average hourly beam radiation on the tilted surface in $\left(\mathrm{W} / \mathrm{m}^{2}\right)$.

\section{Appendix B}

\section{Iterative procedure to find the overall heat transfer coefficient for parabolic trough collectors}

The properties of air $\left(\rho_{w}, \mu_{w}, k_{w}\right)$ are found at the average temperature.

$$
R_{e w}=\frac{\rho_{\mathrm{w}} \mathrm{U}_{\mathrm{w}}}{\mu_{\mathrm{w}}}
$$

McAdams (1954) correlation is used to find Nusselt number for air across the glass cover [15]:

$$
\begin{gathered}
\mathrm{Nu}=0.4+0.54 R_{e w}{ }^{0.52} \text { For } 0.1<\mathrm{Re}<1000 \\
\mathrm{Nu}=0.3 R_{\text {ew }}{ }^{0.6} \text { For } 1000<\mathrm{Re}<50000
\end{gathered}
$$

and

$$
\mathrm{h}_{\mathrm{w}}=\frac{\mathrm{Nu} \mathrm{k}}{\mathrm{D}_{\mathrm{g} 0}}
$$

Where $\mathrm{D}_{\mathrm{g} 0}$ is the outer diameter of glass cover.

Following equation is used to find overall heat loss coefficient $\left(U_{L}\right)$ which is based on receiver area $\left(A_{r}\right)$.

$$
\mathrm{U}_{\mathrm{L}}=\left(\frac{\mathrm{A}_{\mathrm{r}}}{\left(\mathrm{h}_{\mathrm{w}}+\mathrm{h}_{\mathrm{r}, \mathrm{g}-\mathrm{a}}\right) \mathrm{A}_{\mathrm{g}}}+\frac{1}{\mathrm{~h}_{\mathrm{r}, \mathrm{r}-\mathrm{g}}}\right)^{-1}
$$

Where; $h_{r, g-a}$ represents linearized radiation coefficient between glass cover and ambient, and calculated as;

$$
\mathrm{h}_{\mathrm{r}, \mathrm{g}-\mathrm{a}}=\varepsilon_{\mathrm{g}} \sigma\left(\mathrm{T}_{\mathrm{g}}+\mathrm{T}_{\mathrm{a}}\right)\left(\mathrm{T}_{\mathrm{g}}^{2}+\mathrm{T}_{\mathrm{a}}^{2}\right)
$$

$\mathrm{h}_{\mathrm{r}, \mathrm{r}-\mathrm{g}}$ represents linearized radiation coefficient between absorber and glass cover which is;

$$
\mathrm{h}_{\mathrm{r}, \mathrm{r}-\mathrm{g}}=\frac{\sigma\left(\mathrm{T}_{\mathrm{r}}+\mathrm{T}_{\mathrm{g}}\right)\left(\mathrm{T}_{\mathrm{r}}^{2}+\mathrm{T}_{\mathrm{g}}^{2}\right)}{\frac{1}{\varepsilon_{\mathrm{r}}}+\frac{\mathrm{A}_{\mathrm{r}}}{\mathrm{A}_{\mathrm{g}}}\left[\frac{1}{\varepsilon_{\mathrm{g}}}-1\right]}
$$

Where $A_{g}$ is the outside area of glass cover, $\varepsilon_{g}$ is the glass cover emissivity, $\mathrm{T}_{\mathrm{r}}$ is absorbance temperature (assumed to be constant along a segment of the receiver) and $\mathrm{T}_{\mathrm{g}}$ is the glass cover temperature.

The energy balance in the receiver tube is calculated as;

So;

$$
A_{g}\left(h_{r, g-a}+h_{w}\right)\left(T_{g}-T_{a}\right)=A_{r} h_{r, r-g}\left(T_{r}-T_{c}\right)
$$

$$
\mathrm{T}_{\mathrm{g}}=\frac{\mathrm{A}_{\mathrm{r}} \mathrm{h}_{\mathrm{r}, \mathrm{r}-\mathrm{g}} \mathrm{T}_{\mathrm{r}}+\mathrm{A}_{\mathrm{c}}\left(\mathrm{h}_{\mathrm{r}, \mathrm{g}-\mathrm{a}}+\mathrm{h}_{\mathrm{w}}\right) \mathrm{T}_{\mathrm{a}}}{\mathrm{A}_{\mathrm{r}} \mathrm{h}_{\mathrm{r}, \mathrm{r}-\mathrm{g}}+\mathrm{A}_{\mathrm{c}}\left(\mathrm{h}_{\mathrm{r}, \mathrm{g}-\mathrm{a}}+\mathrm{h}_{\mathrm{w}}\right)}
$$

$\mathrm{U}_{0}$ which is the overall heat transfer coefficient inside the pipe is fond as;

$$
\mathrm{U}_{0}=\left(\frac{1}{\mathrm{U}_{\mathrm{L}}}+\frac{\mathrm{D}_{0}}{\mathrm{~h}_{\mathrm{fi}} \mathrm{D}_{\mathrm{i}}}+\frac{\mathrm{D}_{0} \ln \left(\mathrm{D}_{0} / \mathrm{D}_{\mathrm{i}}\right)}{2 \mathrm{k}}\right)^{-1}
$$

The collector efficiency factor $(\bar{F})$ is found by using the following formula;

$$
\overline{\mathrm{F}}=\frac{\mathrm{U}_{0}}{\mathrm{U}_{\mathrm{L}}}=\frac{1 / \mathrm{U}_{\mathrm{L}}}{\frac{1}{\mathrm{U}_{\mathrm{L}}}+\frac{\mathrm{D}_{0}}{\mathrm{~h}_{\mathrm{fi}} \mathrm{D}_{\mathrm{i}}}+\left(\frac{\mathrm{D}_{0}}{2 \mathrm{k}} \ln \frac{\mathrm{D}_{0}}{\mathrm{D}_{\mathrm{i}}}\right)}
$$

Finally, the useful energy for one segment of the collector $\left(Q_{U}\right)$ is calculated by below formula;

$$
\mathrm{Q}_{\mathrm{U}}=\mathrm{F}_{\mathrm{R}}\left[\mathrm{G}_{\mathrm{b}} \eta_{0} \mathrm{~A}_{\mathrm{a}}-\mathrm{A}_{\mathrm{r}} \mathrm{U}_{\mathrm{L}}\left(\mathrm{T}_{\mathrm{i}}-\mathrm{T}_{\mathrm{a}}\right)\right]
$$

where; $F_{R}$ is the heat removal factor which is given by;

$$
\mathrm{F}_{\mathrm{R}}=\frac{\dot{\mathrm{m} C p}}{\mathrm{~A}_{\mathrm{r}} \mathrm{U}_{\mathrm{L}}}\left[1-\exp \left[-\frac{\mathrm{A}_{\mathrm{r}} \mathrm{U}_{\mathrm{L}} \overline{\mathrm{F}}}{\dot{\mathrm{m} C p}}\right]\right]
$$

Also, the useful energy is given by:

then;

$$
\mathrm{Q}_{\mathrm{U}}=\dot{\mathrm{m} C p}\left(\mathrm{~T}_{0}-\mathrm{T}_{\mathrm{i}}\right)
$$

$$
\mathrm{T}_{0}=200+\frac{\mathrm{Q}_{\mathrm{U}}}{\dot{\mathrm{mCp}}}
$$

